\title{
Incidence and Distribution of Raspberry bushy dwarf virus in Commercial Red Raspberry (Rubus idaeus) Crops in Scotland
}

\author{
Jane Chard and Susan Irvine, Scottish Agricultural Science Agency, 82 Craigs Road, Edinburgh EH12 8NJ, \\ Scotland; Adrian M. I. Roberts and Ian M. Nevison, Biomathematics and Statistics Scotland, James Clerk \\ Maxwell Building, Kings Buildings, Edinburgh EH9 3JZ, Scotland; Wendy J. McGavin and A. Teifion Jones, \\ Scottish Crop Research Institute (SCRI), Invergowrie, Dundee DD2 5DA, Scotland
}

\begin{abstract}
Chard, J., Irvine, S., Roberts, A. M. I., Nevison, I. M., McGavin, W. J., and Jones, A. T. 2001. Incidence and distribution of Raspberry bushy dwarf virus in commercial red raspberry (Rubus idaeus) crops in Scotland. Plant Dis. 85:985-988.

A survey was done in 1998 to determine whether Raspberry bushy dwarf virus (RBDV) was established in raspberry fruiting plantations in Scotland. Raspberry-producing holdings were selected according to geographical area and size. Samples (201), each comprising 60 shoots per stock, were obtained from 77 holdings and tested by enzyme-linked immunosorbent assay (ELISA). ELISA-positive shoots from each infected stock were grafted onto cultivar Glen Clova, which is resistant to the Scottish-type isolate of RBDV (RBDV-S), to establish whether the virus is a resistance-breaking (RB) isolate. RBDV was detected in $22 \%$ of the stocks sampled, with 2 to $80 \%$ incidence of infection. No RBDV was in any of the 40 plantations containing cultivars resistant to RBDV-S or in Glen Clova plants, which were grafted successfully with samples from 15 infected plantations, indicating that no RB isolates were detected. The percentage of infected plantations increased with time from the planting date. In order to investigate possible sources of infection, ELISA for RBDV was made in 1999 on samples of stocks of raspberry cultivars entered for the lowest certified grade (Standard Grade) in Scotland and, in 1994 to 1997, on certified stocks planted with material originating from outside Scotland. No RBDV was detected in any of the samples. RBDV was found only rarely in samples of wild raspberry in Angus and Perthshire.
\end{abstract}

Additional keyword: certification

Raspberry bushy dwarf virus (RBDV), genus Idaeovirus, occurs in Rubus species worldwide (11). In some raspberry (Rubus idaeus var. idaeus and $R$. idaeus var. strigosus) and blackberry cultivars and Rubus hybrids, RBDV induces yellows disease and/or crumbly fruit and/or degeneration in vigor $(10,11)$. In North America, New Zealand, and parts of Europe, the increasing incidence and effects of RBDV infection on production and fruit quality in Rubus spp. crops is causing concern $(9,13,14,16,18,19)$. In nature, the virus is transmitted to progeny seedlings through the ovule and among flowering plants through infected pollen. No other means of natural spread is known (11). Control of the virus in crops is therefore dependent upon planting healthy material in isolation from sources of possible infection or, where RBDV is common, growing RBDV-resistant cultivars.

In the U.K., studied field isolates of RBDV show very similar properties, al-

Corresponding author: A. T. Jones

E-mail: tjones@scri.sari.ac.uk

Accepted for publication 25 May 2001.

Publication no. D-2001-0702-03R

(C) 2001 The American Phytopathological Society though two distinct categories of isolate are recognized (11). The most widespread in the U.K. and overseas are S-category isolates. These have biological properties similar to the Scottish-type isolate (D200) and are unable to infect Rubus spp. cultivars containing the RBDV resistance gene $B u(2,11,13,18)$. The other category of isolates, termed RB, is similar in serological properties and symptomatology in herbaceous test plants to $\mathrm{S}$ isolates but is distinguishable because it infects $B u$ genecontaining plants, Rubus species, and cultivars resistant to $\mathrm{S}$ isolates $(2,11)$. Such $\mathrm{RB}$ isolates therefore pose a problem for control.

In the U.K., past incidence of RBDV in commercial Rubus spp. crops has been generally low as a result of the widespread cultivation of raspberry cultivars that express the $B u$ gene such as Delight, Glen Clova, Malling Admiral, Malling Orion, and Malling Jewel $(2,13)$. Indeed, in a survey of RBDV in commercial raspberry crops in England, Barbara and coworkers (1) detected the virus in cultivar Norfolk Giant, which is infectible with the Scottish-type isolates of RBDV (RBDV-S) but not in any of the 12 other cultivars. More recently, a new generation of raspberry cultivars have dominated commercial production within the U.K. and many of these are infectible with RBDV-S isolates such as Glen Moy, Glen Prosen, and in England and Wales, also Autumn Bliss and Leo $(8,10,11,12)$. The effect of this widespread change in cultivars on the incidence of RBDV infection in crops is not reported in detail, but RBDV is believed to be common in crops in England and Wales $(9,14)$ (D. J. Barbara, A. T. Jones, unpublished data).

In the survey, for RBDV in England and Wales reported in 1985 (1), RBDV$\mathrm{RB}$ isolates were reported to be common in commercial loganberry stocks but were not detected in commercial raspberry crops. More recent observations have shown, however, that RBDV-RB isolates are now present and spreading in some commercial raspberry crops in England $(9,14)$ (D. J. Barbara, personal communication).

Because of the increased cultivation of RBDV-infectible cultivars in Scotland and the possible risk of infection with RBDV$\mathrm{RB}$ isolates, the Scottish Executive Rural Affairs Department (SERAD) initiated a statistically based survey to assess the incidence of RBDV in Scottish fruiting raspberry crops and to detect the possible occurrence of RBDV-RB isolates. This paper reports the results from this survey and shows that RBDV is now common in many crops, but no RBDV-RB isolates were detected. It also reports the absence of RBDV in Scottish raspberry stocks entered for certification and the very low incidence of RBDV in wild raspberry in Eastern Scotland.

\section{MATERIALS AND METHODS}

Survey design. The survey data for RBDV infection was based on 201 plantations, at 77 raspberry holdings, in Scotland. Stratified random sampling (3) was used to select the holdings on the basis of the Scottish Office of Agriculture, Environment and Fisheries Department's 1997 agricultural census. In the census, there were 310 holdings growing at least 0.1 ha of raspberry, giving a total of 1,370 ha. It was not known exactly how many plantations were at these holdings, but the total figure was estimated to be 850 to 1,350 .

The random sample was stratified by the area of the crop grown at each holding and by geographical region. The size groupings of the holdings used for stratification were 
0.1 to $0.99,1.0$ to $3.99,4.0$ to $9.99,10.0$ to 19.99 , and over 20 ha. The regions sampled were in Aberdeenshire, Invernesshire, Perthshire, Dundee and Angus, Lothian and the Borders, Fife, and West and Central Scotland. The number of plantations sampled was proportional to the total area of raspberry within the region and to the area covered by the holdings in the size group. At each selected holding, plantations were chosen randomly.

The number of samples per plantation was chosen to provide a good chance to detect RBDV infection, even when the overall number of plants infected was low (5\%). Each selected plantation was therefore divided into 10 approximately equalsized blocks. A primocane shoot (top 30 $\mathrm{cm}$ ) was taken at random from six plants in each block, giving a total of 60 shoots from each plantation.

The information collated for each plantation surveyed was the address of the holding, raspberry cultivar, country of origin of the stock, year of planting, and area of raspberry grown at the holding.

Sampling from spawn beds. Enzymelinked immunosorbent assay (ELISA) for RBDV was made in the summer of 1999 on all stocks of raspberry cultivars entered for the lowest certified grade in Scotland (Standard Grade) and, in 1994 to 1997, on those stocks entered for certification and derived originally from outside Scotland (Table 1). Tests were made in 1999 on 60 randomly selected shoots per spawn bed and, in 1994 to 1997, on 50 shoots per stock.

Statistical analysis. A 95\% confidence interval for the percentage of plantations with RBDV was calculated on the basis of proportional stratified sampling (3), with the different regions as strata. The proportions of plantations infected with RBDV were compared for a number of factors, including cultivar, age of plantation, and size of holding. Fisher's exact test was used to compare two proportions, and the

Table 1. Number of stocks of raspberry cultivars entered for certification and tested for Raspberry bushy dwarf virus in 1994 to 1997 and 1999

\begin{tabular}{lcc}
\hline & \multicolumn{2}{c}{$\begin{array}{c}\text { No. of stocks tested } \\
\text { by year }\end{array}$} \\
\cline { 2 - 3 } Cultivar & $\mathbf{1 9 9 4 - 1 9 9 7}$ & $\mathbf{1 9 9 9}$ \\
\hline Autumn Bliss & 10 & 9 \\
Delight & 0 & 2 \\
Glen Ample & 1 & 3 \\
Glen Clova & 2 & 7 \\
Glen Lyon & 1 & 2 \\
Glen Moy & 4 & 3 \\
Glen Prosen & 17 & 5 \\
Glen Rosa & 1 & 1 \\
Leo & 6 & 5 \\
Malling Admiral & 2 & 4 \\
Malling Jewel & 3 & 6 \\
Other & 4 & 6 \\
Total & 51 & 53 \\
\hline
\end{tabular}

chi-square test was used to compare more than two proportions (5).

The distribution of RBDV incidence was investigated over Scotland, within holdings and plantations. It is possible to test whether the incidence of RBDV was dispersed randomly within or between plantations with use of the binomial dispersion test $(4,7)$, a special type of chi-square test. Because the sample sizes (i.e., number of plantations surveyed per holding or number of plants sampled per block in the plantation) were low, the exact version of the chi-square test was used $(6,17)$ rather than the chi-square distribution test.

Assays for infection with RBDV isolates. The 10 batches of six shoots from each plantation were tested for RBDV by double-antibody sandwich (DAS)-ELISA using a monoclonal antibody to a Canadian isolate of RBDV (15). To determine whether RBDV-RB isolates were present in infected crops, the shoot samples that tested positive for RBDV in ELISA were used at SCRI as scions for bottle grafting to Glen Clova, which is immune to RBDV$\mathrm{S}$ isolates but infectible with RBDV-RB $(2,13)$. The response to graft inoculation of the Glen Clova plants was assessed by DAS-ELISA after overwintering. Results from ELISA were considered positive if they were $3 \times$ or more the $A_{450 \mathrm{~nm}}$ values of uninfected controls.

\section{RESULTS}

RBDV incidence. $R B D V$ isolates and the overall incidence of infection. Of the 201 raspberry plantations sampled, RBDV was detected in 44 (22\%) (Table 2). A 95\% confidence interval for the percentage of RBDV-infected plantations in Scotland was 17 to $27 \%$. More than $20 \%$ of the RBDV infection was detected in 11 plantations $(5 \%)$, and the highest incidence of infection in a plantation was $80 \%$ (Table $3)$.

Infection was not found in any of the 40 plantations containing cultivars Delight, Glen Clova, or Malling Jewel, each known

Table 2. Incidence of Raspberry bushy dwarf virus (RBDV) in raspberry cultivars surveyed in Scotland

\begin{tabular}{lcc}
\hline & \multicolumn{2}{c}{ Raspberry plantations } \\
\cline { 2 - 3 } Cultivar & $\begin{array}{c}\text { No. } \\
\text { surveyed }\end{array}$ & $\begin{array}{c}\text { No. infected } \\
\text { (\% infection) }\end{array}$ \\
\hline Delight & 2 & $0(0)$ \\
Glen Ample & 10 & $0(0)$ \\
Glen Clova & 33 & $0(0)$ \\
Glen Garry & 2 & $0(0)$ \\
Glen Lyon & 10 & $3(30)$ \\
Glen Moy & 64 & $23(36)$ \\
Glen Prosen & 62 & $14(23)$ \\
Glen Rosa & 6 & $1(17)$ \\
Glen Shee & 2 & $1(50)$ \\
Leo & 2 & $1(50)$ \\
Malling Jewel & 5 & $0(0)$ \\
Tulameen & 3 & $1(33)$ \\
Total & 201 & 44 \\
\hline
\end{tabular}

to be resistant to RBDV-S isolates $(2,13)$ (Table 2). Only 57\% (25/44) of the graft inoculations to Glen Clova plants were successful, but none of the plants that were graft inoculated successfully with RBDVinfected shoot samples from 15 plantations became infected. There was, therefore, no evidence from field data or graftinoculation experiments that RBDV-RB isolates were present in Scotland.

Effect of cultivar. Twelve cultivars were tested in the survey, but cultivars Glen Clova, Glen Moy, and Glen Prosen accounted for $80 \%$ of the plantations surveyed (Table 2). Glen Moy had a higher tendency to be infected with RBDV than Glen Prosen when the two cultivars were at the same holding (McNemar's Test, $P=$ 0.016) (5). As noted above, no RBDV was detected in any of the 33 Glen Clova plantations tested or in the few plantations of Delight and Malling Jewel. Glen Moy and Glen Rosa, initially thought to be resistant to RBDV-S $(10,13)$, are now known to be infectible (12; A. T. Jones, unpublished data). If the plantations containing the three RBDV-resistant cultivars are discounted from the total surveyed, RBDV infection was in $27 \%$ of plantations. In the results that follow, the three RBDVresistant cultivars are omitted from the calculations.

Effect of plantation age. The plantations surveyed varied in age from planting from 1 to 19 years (information on age was not available for 15 plantations). The percent of RBDV infection in plantations of $<2,3$ to 5,6 to 8 , and 9 to 19 years was (numbers of plantations in the age groups given in brackets): 14 [36], 25 [69], 33 [27], and 64 [14], respectively. There was strong evidence that the incidence of RBDV in Scotland increased with the age of plantations of RBDV-S infectible cultivars $(P=$ 0.003, chi-square test).

Effect of planting stock source. Of all the plantations surveyed, the origins of the stock were 113 from Scotland, 54 from England, 1 from the U.S.A., and 34 were from mixed or unknown origin. There was no evidence that the incidence of RBDV differed between planting stock from Scotland and England $(P=0.55$, Fisher's exact test).

Effect of holding size. The sizes of holdings surveyed (in terms of area under raspberry cultivation) ranged from less than 1 to almost 50 ha, and there was some evidence that RBDV incidence varied with the size of the holdings $(P=0.06$, chisquare test) (Table 4). There was a higher incidence of RBDV in holdings of less than 4 ha than for larger holdings.

Distribution of RBDV incidence. Geographical distribution. RBDV was found throughout the raspberry-growing regions in Scotland. In large parts of the main raspberry-growing areas (Angus and Perthshire) however, no infection was found (data not shown). 
Distribution within holdings and plantations. Although this survey was not designed to study the aggregation of RBDV within holdings and plantations, the survey results were used in a preliminary assessment. Of the 46 holdings surveyed with two or more plantations, strong evidence was found that if one plantation in a holding was infected, then it was likely that other plantations of RBDV-S infectible cultivars would be infected as well (binomial dispersion test, exact $P=0.0005$ ).

The intracluster correlation coefficient is a measure of aggregation, with a value of 0 , corresponding to no clustering, and an upper limit of 1 . Table 5 shows the intracluster correlation coefficient (7) and the exact $P$ value for a binomial dispersion test in 19 plantations that had more than five infected plants. There was evidence for clustering of RBDV incidence at six plantations of Glen Moy and at one plantation of Glen Rosa (Table 5).

In general, when several fields have been surveyed, the relationship between disease aggregation and disease incidence can be investigated with Taylor's power law (7). In this survey, however, not enough plants were sampled in each plantation to enable any firm conclusions to be drawn.

$R B D V$ in wild Rubus spp. As part of an SCRI survey of the genetic variability in and of gene flow between communities of wild raspberry, plant samples were obtained over a wide area in Angus and Perthshire. These included areas adjacent to, or near, commercial raspberry crops as well as isolated plant communities in rural areas and nonagricultural areas on mountain slopes. ELISA on 153 individual wild raspberry plants detected RBDV only in 19 of these samples. These samples represent only four geographic areas, none of which were close $(<3$ k) to commercial raspberry crops.

$R B D V$ tests on raspberry stocks entered for certification. ELISA did not detect RBDV in any of the raspberry cultivars entered for Standard Grade certification in 1994 to 1997 and 1999 (Table 1).

\section{DISCUSSION}

This work demonstrates the current widespread incidence of RBDV, occurring in $27 \%$ of the RBDV-S-infectible crops sampled in commercial red raspberry crops in all cropping areas of Scotland, with an incidence of $80 \%$ in one crop. Although the infection levels in some plantations were high, there were large parts of the main raspberry-growing region (Perthshire and Angus) where no infection was found (Table 2).
This finding of the widespread incidence of RBDV in crops was unexpected and contrasts with the situation about 20 years ago where it was found only rarely. This situation parallels the similar change in RBDV incidence noted in raspberry crops in England and Wales. In the early 1980s, RBDV was detected rarely in one of 13 raspberry cultivars in England (1), but in 1995 and 1996, 50\% of the farms surveyed in some areas were infected with RBDV (14). The major reason for this great change in RBDV incidence throughout the U.K. seems to be the widespread cultivation of the newer raspberry cultivars such as Autumn Bliss, Glen Moy, and Glen Prosen, which are infectible with common (S) isolates of RBDV. In England and Wales, there is the additional problem of the occurrence and spread in commercial crops of RB isolates that are able to infect cultivars resistant to $S$ isolates (14). There is no indication from our survey, however, that RB isolates are present in Scotland, but this situation should continue to be monitored.

The initial source(s) of RBDV inoculum for the widespread infection of commercial raspberry crops in the U.K. is difficult to identify. In Scotland, our analysis of over 5 years of the planting stock entered for certification (Table 1) gave no indication that infected planting stock was the cause, and similar studies in England have failed to find RBDV in certified stocks (D. J. Barbara and N. Giltrap, personal communication). This contrasts with a recent survey in the Czech Republic, suggesting that infected planting material is an important source of RBDV infection in raspberry crops there (19). Furthermore, in Scotland, as in England and Wales $(1,14)$, wild $R u$ bus idaeus rarely seems infected with RBDV. In Scotland, we detected RBDV only in a few wild raspberry plants, and this occurred in small tight local communities of plants away from major concentrations of commercial crops. Such small and isolated sources seem unlikely to be of great significance in the epidemiology of the virus in commercial crops.

Although the precise inoculum source for the initial infection of RBDV in commercial crops is difficult to identify, because RBDV is spread in association with pollen, once a few plants of a RBDVinfectible crop become infected, presumably the spread within and between such

Table 4. Frequency of Raspberry bushy dwarf virus (RBDV) incidence in relation to holding size, omitting the three RBDV-resistant cultivars Glen Clova, Delight, and Malling Jewel

\begin{tabular}{lcccc}
\hline & \multicolumn{4}{c}{ Size of holdings } \\
\cline { 2 - 5 } Item & $\mathbf{< 4}$ ha & $\mathbf{4 - 1 0}$ ha & $\mathbf{1 0 - 2 0}$ ha & $>\mathbf{2 0}$ ha \\
\hline No. of holdings & 17 & 20 & 20 & 13 \\
No. of plantations & 21 & 43 & 43 & 54 \\
RBDV-infected plantations (\%) & 48 & 21 & 19 & 31 \\
\hline
\end{tabular}

Table 5. Incidence, correlation coefficients and dispersion test results for 19 plantations containing more than five Raspberry bushy dwarf virus-infected plants

\begin{tabular}{llcccc}
\hline Holding & Cultivar & $\begin{array}{c}\text { Planting } \\
\text { year }\end{array}$ & $\begin{array}{c}\text { Infection } \\
\mathbf{( \% )}\end{array}$ & $\begin{array}{c}\text { Intraclass } \\
\text { correlation } \\
\text { coefficient }\end{array}$ & $\begin{array}{c}\text { Dispersion test } \\
\text { significance } \\
\text { probability }\end{array}$ \\
\hline A & Glen Moy & 1986 & 23 & 0.26 & 0.012 \\
A & Glen Prosen & 1984 & 47 & 0.09 & $>0.1$ \\
B & Glen Moy & 1993 & 77 & 0.02 & $>0.1$ \\
B & Glen Prosen & 1994 & 13 & 0.11 & $>0.1$ \\
C & Glen Moy & 1989 & 35 & -0.06 & $>0.1$ \\
D & Glen Prosen & 1995 & 28 & 0.06 & $>0.1$ \\
E & Glen Prosen & 1991 & 13 & 0.04 & $>0.1$ \\
F & Glen Moy & 1990 & 15 & 0.58 & $<0.001$ \\
F & Glen Moy & 1989 & 8 & 0.21 & 0.054 \\
G & Glen Moy & 1992 & 8 & 0.50 & 0.001 \\
H & Glen Prosen & 1994 & 8 & 0.02 & $>0.1$ \\
I & Glen Moy & 1991 & 28 & 0.02 & $>0.1$ \\
I & Glen Lyon & 1994 & 47 & -0.06 & 0.1 \\
J & Glen Moy & 1997 & 10 & 0.39 & $>0.1$ \\
K & Glen Moy & 1990 & 72 & 0.02 & $>0.1$ \\
K & Glen Prosen & 1996 & 77 & -0.03 & $>0.1$ \\
K & Glen Lyon & 1995 & 80 & 0.11 & $>0.001$ \\
L & Glen Moy & 1995 & 55 & 0.61 & $>0.001$ \\
M & Glen Rosa & 1997 & 8 & 0.50 & \\
\hline
\end{tabular}

Table 3. Frequency of Raspberry bushy dwarf virus (RBDV) infection levels in raspberry plantations in 1996

\section{\% RBDV infection}

\begin{tabular}{lcccccccccccc} 
& $\mathbf{0}$ & $\mathbf{1 - 1 0}$ & $\mathbf{1 1 - 2 0}$ & $\mathbf{2 1 - 3 0}$ & $\mathbf{3 1 - 4 0}$ & $\mathbf{4 1 - 5 0}$ & $\mathbf{5 1 - 6 0}$ & $\mathbf{6 1 - 7 0}$ & $\mathbf{7 1 - 8 0}$ & $\mathbf{8 1 - 9 0}$ & $\mathbf{9 1 - 1 0 0}$ \\
\hline No. of plantations & 157 & 30 & 3 & 3 & 1 & 2 & 1 & 0 & 4 & 0 & 0 \\
\hline
\end{tabular}


crops is likely to be rapid. There was some evidence, however, that RBDV incidence within plantations was not randomly distributed and may tend to occur in clusters (Table 5). The spatial distribution of RBDV within crops in Scotland is therefore worthy of further study.

In western North America, the incidence of RBDV differs markedly between British Columbia-northern Washington and southern Washington-Oregon, despite the fact that, in both regions, the same cultivars are grown and growers use honeybees for pollination (16). This indicates that other factors, presently unknown, may have an important impact on the transmission of RBDV in raspberry crops. Further detailed studies on the spread of RBDV over time from crop to crop and farm to farm in Scotland may be worthwhile because such information could prove useful for devising improved management of this difficultto-control virus in crops.

\section{ACKNOWLEDGMENTS}

We thank the many growers whose crops were sampled in this survey for access to their plantations, the SERAD horticultural inspectors and A. Mitchell for assistance in collecting the samples, and the SERAD policy staff for encouragement and advice. Work at SCRI is aided by a grant from SERAD.
LITERATURE CITED

1. Barbara, D. J., Ashby, S. C., and Knight, V. H. 1985. The occurrence and distribution of isolates of raspberry bushy dwarf virus. Ann. Appl. Biol. 106:75-81.

2. Barbara, D. J., Jones, A. T., Henderson, S. J., Wilson, S. C., and Knight, V. H. 1984. Isolates of raspberry bushy dwarf virus differing in Rubus host range. Ann. Appl. Biol. 105:4954.

3. Barnett, V. 1974. Pages 76-108 in: Elements of Sampling Theory. English Universities Press, London.

4. Cochran, W. G. 1954. Some methods for strengthening the common $\chi^{2}$ tests. Biometrics 10:417-451.

5. Everitt, B. S. 1992. The Analysis of Contingency Tables. Chapman and Hall, London.

6. Good, P. 1993. Permutation Tests. SpringerVerlag, New York.

7. Hughes, G., Madden, L. V., and Munkvold, G. P. 1996. Cluster sampling for disease incidence data. Phytopathology 86:132-137.

8. Jones, A. T. 1988. The influence of cultivating new raspberry varieties on the incidence of viruses in raspberry crops in the U.K. Aspects Appl. Biol. 17:179-186.

9. Jones, A. T., and Allen, J. 1995. On the trail of a pollen-borne disease. Fruit Grower Jan:1416.

10. Jones, A. T., and McGavin, W. J. 1998. Infectibility and sensitivity of U.K. raspberry, blackberry and hybrid berry cultivars to $R u$ bus viruses. Ann. Appl. Biol. 132:239-251.

11. Jones, A. T., Mayo, M. A., and Murant, A. F. 1996. Raspberry bushy dwarf virus. Pages 283-301 in: Viruses with Isometric Particles and Bipartite Genomes. B. D. Harrison and A. F. Murant, eds. Plenum Press, New York.

12. Jones, A. T., McGavin, W. J., Mayo, M. A., and Graham, J. 1998. Natural infection with raspberry bushy dwarf virus (RBDV) of the putatively RBDV-resistant red raspberry cultivar Glen Moy, and the demonstration that it does not contain the RBDV resistance gene, Bu. Ann. Appl. Biol. 133:403-414.

13. Jones, A. T., Murant, A. F., Jennings, D. L., and Wood, G. A. 1982. Association of raspberry bushy dwarf virus with raspberry yellows disease; reaction of Rubus species and cultivars, and the inheritance of resistance. Ann. Appl. Biol. 100:135-147.

14. Knight, V. H., and Barbara, D. J. 1999. A review of raspberry bushy dwarf virus at HRIEast Malling and the situation on a sample of commercial holdings in England in 1995 and 1996. Acta Hortic. 505:263-271.

15. Martin, R. R. 1984. Monoclonal antibodies define three antigenic regions on raspberry bushy dwarf virus. Can. J. Plant Pathol. 6:264.

16. Martin, R. R. 1999. Raspberry viruses in Oregon, Washington and British Columbia. Acta Hortic. 505:259-262.

17. Mehta, C. R., and Patel, N. R. 1983. A network algorithm for performing Fisher's exact test in $\mathrm{r} \times \mathrm{c}$ contingency tables. J. Am. Stat. Assoc. 78:427-434

18. Murant, A. F., Jones, A. T., and Jennings, D. L. 1982. Problems in the control of raspberry bushy dwarf virus. Acta Hortic. 129:77-88.

19. Spak, J., and Kubelková, D. 2000. Epidemiology of raspberry bushy dwarf virus in the Czech Republic. J. Phytopathol. 148:371377. 